\title{
A Place for Digital Storytelling in Teacher Pedagogy
}

\author{
Anne-Marie Clarke \\ Queens University, Belfast, N. Ireland
}

Copyright $@ 2017$ by authors, all rights reserved. Authors agree that this article remains permanently open access under the terms of the Creative Commons Attribution License 4.0 International License

\begin{abstract}
Traditional school subjects are challenged by the acceleration of access to knowledge in the new age of media available to both teachers and students. Teachers who are socialized into existing traditional practices are now encouraged to introduce technology into their pedagogy. This Paper explores a particular way in which teachers can creatively introduce a new and useful technology known as Instructional Digital Storytelling (IDS), guided by the Technological, Pedagogical and Content framework (TPACK) developed by Mishra and Koehler [1]. It illustrates how, through narrative inquiry, teacher experience of both the creation and use of Digital Storytelling for instructional purpose in a Secondary School setting, highlighted challenges, rewards, accelerated learning and developed a community of practice across subject disciplines. The focus is on the reconstruction of the experience of creating a Digital Story on four levels: a) Internal structures of blending voice over, imagery and sound to create a successful IDS; b) Experience of challenges and negotiations in crafting the story; c) Experience of sharing with students; d) Recognition of themes and patterns which may have emerged among the participants.
\end{abstract}

Keywords Digital Storytelling, Community of Practice, Technology Pedagogy Content Knowledge (TPACK) Instruction, Reflection

\section{Introduction}

This Paper is based on research carried out with four Irish Post-Primary school teachers who were invited to integrate a new technology known as Instructional Digital Storytelling (IDS) into their pedagogy. Maeve was a teacher of Business Studies, Louk Mathematics; Fintan English and Iosef Design Communication Technology (DCG). The invitation resulted from personal experience of what I found to be successful in the process of teaching and learning. I wished to share my experience to see if it might be as effective for others. As a practitioner, based in the same school as the four participating teachers, I was also developing a form of continual professional development by initiating and engaging other teachers in a structured inquiry which involved learning about, developing and implementing technology in a meaningful way in their classrooms. It involved integrating technology with a story which could either be used to introduce or explain a concept, solve a problem, illustrate an example or inspire students.

The Teaching Council of Ireland had recently consulted with teachers to learn about their experiences of professional learning. The result was a Draft Consultation Paper Cosán [2] which proposed autonomy for teachers to engage in professional development. This inquiry was an exploration of the challenges of such an endeavor at a local, school level. It explored the challenges, rewards and limitations which four teachers faced while engaging with Instructional Digital Storytelling and whether they perceived the process of this experience as positive and effective. It sought to understand whether the creation of Digital Stories stimulated the development of their technological, pedagogical and content knowledge (TPACK), a framework which Mishra [3] argues is a requirement for successful teaching in the twenty-first century.

The methodology was positioned within narrative inquiry, which concentrated on the voice of teacher experience. It involved listening to the teachers' individual stories of their experience, and a meta-narrative of their pedagogical stories was developed. The design comprises two forms of story as data. The first form is an Instructional Digital Story (IDS) developed by each teacher for use in a curriculum lesson within their subject area. The second form is a Reflective Digital Story (RDS) about each teacher's experience of creating and using the IDS. The second form of Digital Story (RDS) adopts a broader approach to a narrative inquiry where participants usually voice personal stories of experience during interviews and discussions.

\section{Rationale}

The Organization for Economic Co-operation and Development [4] carried out a survey of Teaching and Learning at International level (TALIS), which focused on certain aspects of professional development for each of the 
twenty-four participating countries, of which Ireland was one. One of the four areas identified for development in Ireland was technology. The purpose of TALIS was to 'assist countries to review and develop policies to make the teaching profession more attractive and more effective' ( $\mathrm{p}$. 3). In response to TALIS, the Teaching Council of Ireland [5] developed a policy on the Continuum of Teacher Education to include the areas identified for Ireland. The policy stated that following initial teacher education and induction, provision and resources should be provided to enable teachers to develop and build on 'innovation, integration and improvement' (p.10). Alongside continual professional development (CPD) provision by the Department of Education and Skills (DES), teachers in Ireland are currently encouraged to take responsibility for and shape their professional learning, to evaluate their pedagogical beliefs and practices and to engage in collaboration. Teachers are also encouraged to share their expertise and experience with other teachers as part of a cascading process.

Within Irish secondary schools, professional development, under the leadership of a Joint Managerial Body (JMB) takes place as part of the teaching contract and is led by school management. Traditionally, this takes the form of outside facilitator presentations and staff collaboration within subject departments during a time set aside for planning. Subject in-service is also organized by the Professional Development for Teachers (PDST) within Education Centres over the course of the academic year. In total, teachers are required to engage in a minimum compulsory thirty-two hours of professional development each academic year.

Within this context, there were two strands which combined to determine interest in developing this inquiry into teachers' experiences of creating and using IDS. One of these, as already stated, related to the curiosity that was stimulated as a result of my developing relationship with Digital Story. The other grew out of readings around research and educational policy in Ireland that focused on what either helped or hindered student's learning and the potential role that technology could play in enhancing meaningful learning.

Creating a Digital Story is a relatively simple process, but the creation of an interesting one is artful. Furthermore, the creation of one for instruction in the form of IDS is a challenging experience. This led me to focus on challenges teachers of different subjects may experience while creating an IDS and the values and attitudes they attach to that experience. The conceptual framework chosen for IDS is technology, pedagogy and content knowledge (TPACK). Knowledge in all three domains is necessary for the creation of IDS. The definition used for IDS stems from the design promoted by the Centre for Digital Storytelling (CDS) in Berkley, California [6]. Relating Storytelling to TPACK: 'The modern expression of the ancient art of storytelling: It uses digital media to create media rich stories to tell, to share, and to preserve'.

The basis of teachers integrating technology with their storytelling pedagogy lays within the work of Shulman [7] and more recently the work of Mishra and Koehler [8]. Shulman [7] originally developed a framework which blended teacher content knowledge with pedagogical knowledge, meaning the teacher transforms subject content in a way which can be understood by learners. This framework later became known as Pedagogy Content Knowledge (PCK) and, in more recent years, was developed by Mishra and Koehler [8] to incorporate what teachers must know about technology. Thus, it was renamed as Technology Pedagogy and Content Knowledge (TPACK). Mishra and Koehler [8] state: 'The basis of our framework is the understanding that teaching is a highly complex activity that draws on many kinds of knowledge. Teaching is a complex cognitive skill occurring in an ill- structured, dynamic environment............. There are clearly many knowledge systems that are fundamental to teaching, including knowledge of student thinking and learning and knowledge of subject matter'. (p. 1020).

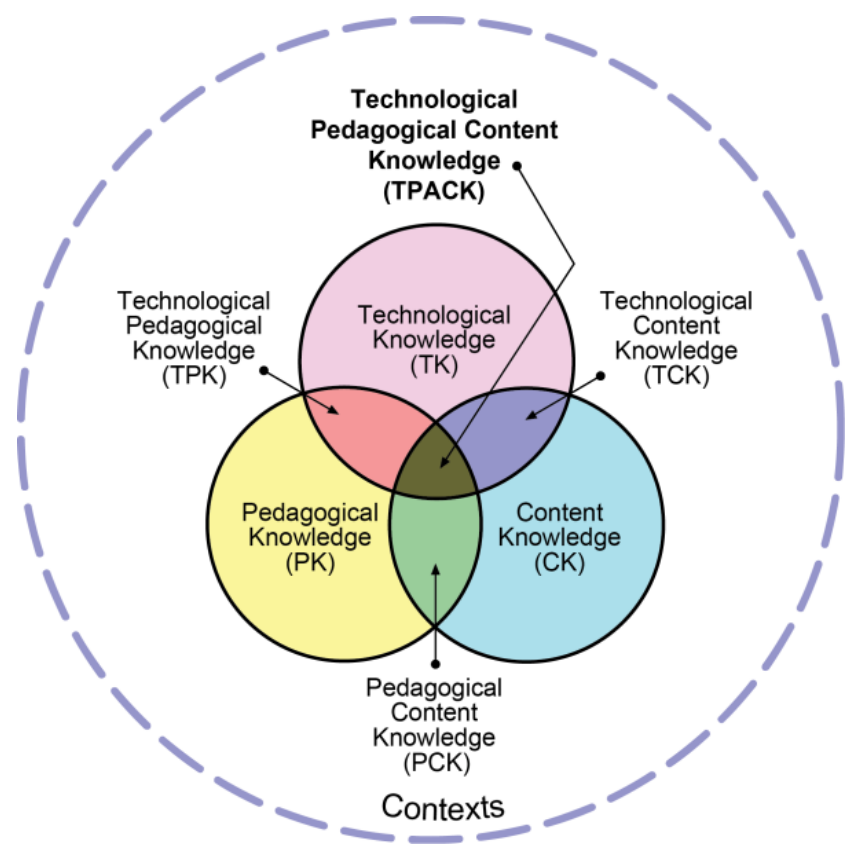

"Reproduced by permission of the publisher, (C) 2012 by tpack.org"

Figure 1. Venn diagram representing intersections of TPACK

Mishra and Koehler [8] argue that teaching should involve all three types of knowledge: technology knowledge (TK) involving skills which relate to standard and more advanced technologies; knowledge of pedagogy (PK) including the methods of teaching and content knowledge (CK) relating to the content to be taught. For explication here, TPACK is set out as a dynamic framework, which can be used to interpret a teacher's experience of gaining knowledge within the domains of technology, pedagogy and content, required for creating and using IDS and RDS.

The role of creating Digital Stories for both instruction and reflection in education is, according to McGee [9], a well-known strategy, especially in pre-service teacher education programmes Ohler [10]; Robin, [11]; Thompson-Long [12]. Stories are explored through the 
concept of story circle in the world of Digital Storytelling, where they are shared before creating them Lambert [13]; McGee [9]; Meadows [14]; Ohler [10]. Such circles serve to develop a sense of bonding among sharing communities according to Lambert [13], who along with Dana Aitchley (at the Centre for Digital Storytelling, California) was the originator of the concept of story circle as an integral component of Digital Storytelling. When teachers collaborate and share stories, they are usually sharing what works or does not work for them in the classroom. It is this type of collaboration which the Teaching Council of Ireland [5] encourages in CPD.

Technology was highlighted in a report by the OECD and UNESCO [15] as an important feature in teacher professional development. It stressed the importance of the teacher having an understanding of its pedagogical use and being trained to integrate it into classroom practice. Llorens et al [16] agreed with this when they drew attention to a digital divide among teachers who had not received adequate support in how to use technology skills. Adopting a similar viewpoint, Lawless and Pellegrino [17] highlighted concerns about the quality and efficacy of teacher training programmes in the USA, suggesting poor training may also create a digital divide between students and teachers. They drew attention to studies which acknowledged high-quality professional development, over a long period, within a meaningful context and which encouraged collaborative learning communities. These studies highlighted the connection of high quality CPD to student achievement Alderman et al [18]; Desimone et al [19]; Sparks [20]. In contrast, several years later in the Irish context, Clarke [21] identified proficiency in usage and technical issues in a project within initial teacher education in the Northern Ireland context. She reported on a pilot project which built on educational technology research in Ulster. Students on an initial teacher education programme were provided with iPads which had basic creative applications, and they were encouraged to use them while on teaching practice. The data collected gave evidence of pedagogical issues which involved confidence in using the iPad.

The integration of technology is described by Mishra and Koehler [1] as a complex issue for many teachers and suggesting that rather than concentrating on the technology itself, professional development programmes should follow the lines of curriculum content and pedagogical approaches to integrating new technologies. This means redesigning programme experiences in order to develop the knowledge teachers need to integrate a particular technology. In addition to this Mishra and Koehler [1] have suggested the context or environment in which teachers work should be taken into account.

\section{Methodology}

Practitioner-based research does not describe the research method employed, but it does define my identity and relationship with the teachers. It had a direct influence on the choice of narrative inquiry and particularly digital narrative. The justification for the inquiry being practitioner-based is because I am a practitioner in education and was eager to gain knowledge about how others experienced what I found to be successful in my own pedagogy. It is also important to highlight that I viewed it as a path which would provide space for experienced teachers to collaborate. The consequence of this type of collaboration was intended to empower teachers to voice their experience as well as enhancing my own knowledge and making a contribution in the field of research.

\subsection{Why Narrative?}

Narrative inquiry is defended by Clandinin [22], who maintains it is growing in acceptance in the field of social research. It is the study of experience by listening to participant voices. It involves "collaboration between researcher and participants, over time, in a place or series of places, and in social interaction with milieus." Clandinin and Connolly [23] p.20. Several inter-related reasons for using narrative are also described by Cortazzi [24] as: 'concern with the meaning of experience, voice, human qualities on the personal and professional dimensions, and research as a story' (p. 385). I considered all of these reasons, viewing them as reliable introductions to personal and professional lives as well as identities Clandinin \& Connolly [23]; Connelly \& Clandinin [25]; Doecke et al. [26]; Goodson [27]; Jalonga et al. [28]. Also guiding my choice of narrative was the work of Raymond et al. [29] and Elbaz-Luwisch [30]who, along with Cortazzi [24], promote narrative as representing the meaning of experience and encouraging participant voice. I was conscious of ongoing narratives all the time, although there were times when narrative was deliberately engaged as part of the research process.

The aim was to highlight not only moments of experience when digitizing instructional stories but also the complex landscape for the school curriculum within which they were created and used. Influenced by the words of Etherington [31] who, while discussing the variety of meanings attached to narrative research stated ' $w$ hat does seem important is that I describe what it means to me (at this point) and the assumptions and ideas upon which my practices are based' (p.71). When teachers talked about their pedagogy of teaching and the type of technology they used, they were discussing what already works or does not work in their lessons.

\subsection{Narrative as Story}

The use of narrative to gain knowledge of participant experience engaged the art of story, a view shared by narrative researchers who believe we live storied lives in a storied world Etherington [31]; Gergen and Gergen,[32]; Sarbin, [33]. Narrative is not simply a mirror or reflection of 
reality, as it often shapes it Connelly\& Clandinin [34]; Smith $\&$ Sparkes [35]. Mishler, in conversation with Clandinin and Murphy [36] differentiated between narrative analysis and analysis of narrative, describing the former as a general form of qualitative research where the researcher organizes data into themes and categories. While narrative analysis 'understands lives as unfolding temporarily, as particular events within a particular individual's life. The final result is a story'(p.642). I was conscious of the shift Johnson [37] describes as developing from the single mode of voice to multimedia forms. I also heeded a warning by Gomez et al. [38] about the importance of sensitivity when investigating personal stories. This strengthened my decision to use RDS as a method to gain a deeper sense of teacher experience.

\subsection{Reflective Digital Stories}

Lambert [39] describes Digital Story as a form of reflective practice, suggesting work which requires creativity uses a component of effort, requiring deeper reflection. For the creators of the RDS, it offered the chance to relive and re-evaluate experience. It provided a potential opportunity to write about experiences which maintained temporality, sociality and place as described by Clandinin and Connelly [23]. By seeking experience through digital narratives, which required participants to speak their own words, edit them and combine this with image and sound, it carried a powerful meaning as a reflective practice. Conscious that one of the challenges often facing narrative inquiry is how the participant is represented in the data; the creation of RDS' gives real-time to the voices of the teachers and enables them to represent their data. In addition to this Lambert [13] suggests the use of self-narrative in the creation of a digital story can lead to a new realization and further insights. Lambert [39] describes reflecting in digital story form as a means of encouraging the creator to consider issues that are important to them, as well as an awareness of why. The RDS was created after a second workshop and was a key factor to the participants' evolving sense of using Digital Story (DS). By editing voice with a mix of images and sound which carried 'their own powerful meaning' p.27 Lambert [39] they had an opportunity to potentially develop what Denzin [40] refers to as a re-lived epiphany.

\subsection{Selection of participants.}

Teachers of English, Mathematics, Business Studies and Design Communication Technology (DCG) within the school where I taught were invited to participate in the research. These subjects were chosen on the basis of English and Mathematics being core subjects and Business Studies and DCG being popular foundation subjects. Core subjects are compulsory for all students while foundation subjects are chosen because students have a particular interest in studying a particular subject. All four subjects have a history of traditional instruction.
Conscious of the fact that these teachers were and would continue to be my colleagues and they might feel obliged to say 'yes', a detailed explanation stating they were under no obligation to join the research group was provided in a letter. Consent forms further outlined the commitment. The four teachers were selected from a short list based on the criteria of teaching Junior Cycle, use of story for instruction and integration of technology into pedagogy.

Workshops were provided outside of school hours, off school premises, which instructed the teachers on how to create and use DS, which enabled them to become familiar with the phenomenon of it and gave an opportunity to have future meaningful discussions. The place organized for the workshops and discussions was at a local hotel. It was important to separate personal school agendas, held by each teacher, from the focus of the research. The place where the teachers chose to create the digital stories for instruction and reflection was within the privacy of their homes, away from the disturbance of school bells and other disruptions.

\subsection{IDS Workshop Aims and Objectives}

The aims of the workshop were to: Categories stories as: Case study; narrative; problem solving; scenario Andrews [41]; train the teachers in the process of DS; review their familiarity with the hardware and software and provide any support or information necessary.

The objectives were to facilitate each of the teachers to: choose a category of instructional story suitable to subject and age of students in their chosen Junior Cycle class; define purpose of the IDS with specific topics and learning goals through the process of story circle; develop technology knowledge in the use of software; practice and develop appropriate voice pitch and pace; integrate as necessary the power of metaphor into the story; choose appropriate symbolic or visual images and choose music/sound which can be used in an emotive and evocative way.

The teachers were able to access visual material, links and notes for digital story telling through a shared folder using 'Dropbox'. This downloadable free cloud storage service allowed participants to share files.

During the workshop a distinction between storytelling and Digital Storytelling was based on Porter's [42] experience of Lambert's Storytelling workshop. She promotes storytelling as an art form using the Story ARC involving six elements which turn tales into stories. She contends the main character of any media production needs to be the ARC. The aim of the digital medium is to create sensory feelings for the unfolding of the innate qualities of the story. This indicates that lessons learned and 'living in ' the story need to be developed before the Story ARC can unfold. The first element is living in the story, where the author, who does not have to be the main character, carefully chooses words and pitch of voice in order to create an emotional connection.

Porter maintains the voice-over creates an opportunity for 
an emotional journey for both the author and viewer to 'live' the story. The second element, lessons learned and understanding gained, lies within the ARC which has a particular point to it. The understanding taken from the knowledge of the story develops a spine. The spine helps deal with the third and fourth elements of tension which creates a hook for the listener and economy of the story, such as what is left in and what is left out during the editing process. This is the process which ultimately impacts on the viewers in the final version of the story. The fifth element is the visual detail interwoven with the spoken word so the obvious does not have to be stated. The sixth element is craftsmanship where the creator uses technology in a creative way. These elements rely heavily on the importance of the creator using well researched content $(\mathrm{CK})$ and developing it in a creative way as an instructional story (PCK) appropriate to the subject before enhancing it with technology (TPACK). While it is useful to look at all three areas separately, it is necessary for all three to converge for the master teacher using Digital Story.

\subsection{Workshop for Reflective Digital Story}

The process of story circle served to encourage the teachers to share reflections on their experience of creating and using IDS. The aim of the workshop was to encourage the teachers to engage in reflection on their experience of creating the IDS. The objectives were to encourage each of the four teachers to use the process of story circle to share challenges, rewards and negotiations made while creating and using the IDS; examine these challenges, rewards and negotiations in detail and make sense of personal experience through story.

\subsection{Method of Analysis}

From the very start of the inquiry I developed a habit of writing and drawing memos of things I noticed during story circle, workshops, comments made by the teachers, responses when organizing meetings and periods of silence. Some of the memos served to triangulate data, which was gathered through recorded interviews, discussion, story circle and the RDS. All of these served to clarify subsequent coding of themes and analysis of data.

Charmaz [43] describes memos as serving a variety of purposes in an inquiry, but stresses their role in creating theoretical categories. As I wrote the memos, particularly during the story circle process prior to creating the IDS and RDS, I developed themes based on my interpretation of what I perceived to be the experience of each participant. I added these to the ones initially derived from the research questions and literature review, based around the seven elements of technological, pedagogical and content knowledge which Mishra [3] perceives as knowledge a teacher requires to teach successfully. I developed colour codes for each of the themes emerging from research questions during interviews (Table 1) Using these colour codes I further analyzed the narrative data produced from transcribed voice recordings of interviews and story circle and developed sub-themes using a pen and paper system (Table.2). This involved reading the transcript at least four times, once for the whole story, then listening to the first person voice and the relational voice of their experience and finally to develop my interpretation of the meaning behind the voice. These themes served to provide information for the data analysis and discussion. Each of the following grids shows the process of analysis.

Table 1. Themes from data collected during interviews, story circle and RDS

\begin{tabular}{|c|c|c|c|c|}
\hline Beliefs & Challenges & Negotiations & Emotions & Aim of IDS \\
\hline $\begin{array}{c}\text { Use of story; } \\
\text { Classroom management; Personal stories }\end{array}$ & $\begin{array}{c}\text { Topic; Time; Deciding } \\
\text { images; creating story }\end{array}$ & $\begin{array}{c}\text { Mixed ability classes; } \\
\text { curriculum; learning styles }\end{array}$ & Nervous, pride & Deep understanding \\
\hline
\end{tabular}

Table 2. Sub-themes developed from the main themes

\begin{tabular}{|c|c|c|c|}
\hline Values & Attitudes & CPD \\
\hline $\begin{array}{c}\text { Technology; story; developing } \\
\text { pedagogy; student ability; student } \\
\text { learning; CPD; time }\end{array}$ & $\begin{array}{c}\text { Whatever works for me; learning is better when } \\
\text { linked to real life; deep understanding; visuals; } \\
\text { personal approach; deep understanding }\end{array}$ & $\begin{array}{c}\text { Lots of attendance at } \\
\text { in-service; } \\
\text { experimenting }\end{array}$ & $\begin{array}{c}\text { Contract hours for CPD; subject } \\
\text { departments and associations; first } \\
\text { time collaborating across subjects }\end{array}$ \\
\hline
\end{tabular}


Coding was based on frequency of observed behaviour noted in my research memos and comments made by the participants during interviews, story circle and RDS. The memos were used in support of comments, such as how the comments were made, for example nodding and shaking of heads, facial expressions and laughter.

The sub- themes which were generated are illustrated in (Table.2). These were taken from references participants made to a specific matter throughout individual interviews. These were then used to analyze the data in relation to each research question as outlined in the main findings.

\section{Main Findings}

In answer to the following question: How does the experience of creating a Digital Story for instruction facilitate the development of Technology, Pedagogy and Content Knowledge? The main findings determined a pedagogical shift took place for each teacher. Identified challenges included choice of content suitable for IDS; pressure to deliver curriculum; suitable images for IDS; recording of voice over; developing a story. The aim of lesson content to be taught influenced the style of IDS. Acceleration of student learning was established. All four teachers described the creation of a Digital Story as time consuming. Two of the teachers did not develop their pedagogy through the use of story.

In answer to the question: 'How does the experience of creating a Digital Story for reflection facilitate the development of Technology, Pedagogy and Content Knowledge? The following findings determined that teachers developed all areas of TPACK in their reflective DS. They learned to enhance RDS by using metaphorical images. RDS deepened teacher reflection and future plans for using IDS were clearly stated. Reflection expressed beliefs and values as an influence on the chosen style of IDS. Two teachers beliefs expressed curriculum guidelines as a limitation to the creation of future IDS. Teachers reflected on everyday creativity used to create IDS.

The main findings resulting from the question: How do teacher values and attitudes throughout the process of creating Digital Story influence their beliefs in practice? All four teachers valued pedagogy which they already deemed to work in teaching and learning. However, they were willing to learn new technology. Time constraints of the curriculum influenced the integration of technology. Several of the teachers valued readily available technology found on the internet.

The main findings determined from the question: How did professional development impact on the development of TPACK for teachers situated within a school environment? Each teacher openly shared knowledge and ideas within story circle. Limitations and challenges of subject disciplines when creating IDS were highlighted and discussed as a result of a collaborative setting. Learning from the experience of others assisted the application of new knowledge when creating RDS. All four teachers reported self-efficacy after using personally created IDS. Two teachers discussed the possibility of creating future libraries of IDS if time could be found during planning.

\section{Discussion}

At the start of the inquiry all four teachers illustrated their perceptions of storytelling and described how they told stories in either first or third person. They explained how they believed this enhanced student understanding of content and concepts they were teaching. However, when asked to plan and create a Digital Story around the aim of a lesson using their $\mathrm{CK}$, two of the teachers were challenged by the common denominator of story and deviated from the art of storytelling which they had earlier described as a method they used to engage student audiences on many levels. They had concurred that it acts as the hook and 'is the best way to convey information' (p.177) Schank et al [44].

Instructional story lies within the pedagogical design of the lesson and it is within the storyboard process where the intersections of TPACK are applied. The content knowledge (CK) is storied; the art of creating the story requires pedagogy knowledge (PK); the storied content therefore requires an understanding of the intersection of PCK; the addition of images and sound necessitates technology knowledge (TK); the knitting together of technology and content develop TCK and the images and sound enhance the pedagogical art of storying TPK. The successful blending of all elements develops TPACK. The teachers who developed IDS using story created a socially mediated lesson. These findings suggest more time and effort should be invested in story circle based on the lesson content, which may challenge the teacher to develop a story core in order to create Digital Stories.

Each teacher demonstrated different confidence levels in the use of story within IDS. Iosef had the opportunity to cut across trans-disciplinary boundaries of technical and mathematical elements by adding a problem to be solved, or a scenario where characters attempted to solve a problem. Had he asked himself questions like 'What will the twelve and thirteen year old students see and hear when they view the IDS? How will they see its relevance to the real world?' he may have been influenced to write a story. Instead, he described how he aimed to teach the basics to junior classes 'because my subject is technical and it's something I wanted to get done in class.' He also described how he felt under pressure to deliver the curriculum which concurs with findings of Ertmer et al. [45] highlighting teacher use of technology as connected to curriculum requirements. He originally described himself as a storytelling teacher and later altered his description, referring story use to teaching senior students only.

When planning his IDS Fintan also did not ask himself 
questions such as 'How will the boys and girls in my class relate to this? How relevant will it be to their experience of travel?' Instead he described how his focus was on the aim of the lesson and only considered the students later when he narrated the words he was encouraging them to use in descriptive writing. It can be argued that Fintan's story is border line to the official definition of Digital Story. He took his audience on an imaginary journey. Although he did not use characters, he did place his students into the story by asking them to imagine themselves walking through the various landscapes of his chosen images (TK) using their listening, feeling and visual senses. This was Fintan's way of overcoming his hesitation to write a script which he would otherwise have told spontaneously. He developed TCK by adding images to his chosen descriptive narration; TPK by creating a video but did not develop CPK because the pedagogical approach for a Digital story is the use of story. He believes his spontaneous storytelling pedagogy has a genuine emotional attachment to his lesson and by digitizing such a story 'I would be contriving'. His video did however, relate to real life situations of walking through different landscapes, and the students were fully engaged. The lesson aim of engaging students in discussion and a writing exercise was also achieved.

Both Maeve and Louk thought deeply about delivering their content differently. They both asked themselves 'How can I deliver this story while also achieving the aim of the lesson?' In her reflection Maeve indicated development of PCK when she described her intention to create a story which would stay with her students for a long time. She illustrated TCK when developing her story process using images of characters and TPK when she described her plans to use the images for future IDS. She holds strong beliefs about the power of story in teaching and learning and described how she found the task exciting in that she was planning to deliver the content of book keeping and petty cash in a different way. Her beliefs in the value of storytelling to promote instruction enabled Digital Storytelling to facilitate her development of TPACK.

Louk developed a story which his students could relate to while also learning the topic, suggesting development of PCK. He holds strong beliefs about relating his lesson content to real life situations, and his beliefs drove his story arc. He demonstrated TPK when he connected with the interests and level of his students by using TCK in selecting images of his daughter as the emotive element rather than using himself as the character. He presented his daughter as a fictional character, assuming the attention of the young second-year students' in his class would be captured by this clearly indicated development of TPACK.

All four teachers had existing pedagogical content knowledge PCK, and they indicated a variety of experiences in using technology for instruction. The workshops provided the specific knowledge required to develop a story around content and how to integrate technology with story. In other words, all four teachers received support in developing TPK.
However, the different subject domains left the teachers without support when developing TPACK. Two teachers (Fintan and Iosef) indicated technology content knowledge TCK development from the experience of creating a video as an IDS, but their beliefs surrounding the use of story hindered the development of the intersection of technology pedagogy TPK facilitated by IDS. Their output indicates they did develop the intersection of pedagogy and content knowledge PCK in that they presented content to their students in a personally creative and engaging way by integrating technology. They reported a high level of self-efficacy after creating and sharing their product. They developed TPACK, but it was not facilitated by Digital Story. Two teachers (Maeve and Louk) embraced the value of story and were creative in presenting their stories, developing all elements of TPACK. They used their content knowledge to create a story, their pedagogical knowledge to create an engaging story for the students in their class and their technology knowledge to enhance the story. They successfully knitted together all three knowledge domains during the process of storyboard and created IDS. This highlights two important factors of belief and creativity.

My analysis of the process and outputs sought to find commonalities of thinking and strategies between teachers from different disciplines when describing their experiences of creating an IDS. I expected the teachers to independently craft a story based either on or around the content or concept as part of their instruction. This did not happen in all cases and points in the direction of a need for further workshops and discussion of using story for instruction.

\subsection{RDS and the Development of Technology Pedagogy and Content Knowledge?}

The collaborative process of the reflective story circle served to identify three factors highlighted by Rodgers [46]:

1. Affirmation of the value of one's own experience. In isolation, what matters can too easily be dismissed as unimportant;

2. Seeing things "newly" -others offer alternative meanings, broadening the field of understanding;

3. Support to engage in the process of inquiry......(p. 357)

Reflections by the teachers were both personal and emotionally charged. Albeit limited within the confines of the task they rendered their stories of personal experience, carefully selecting technology features of imagery and sound which enhanced the deeper meaning of their reflection within a time parameter. The process of editing the story, necessitated by each slide, assisted each teacher in clarifying the meaning of their experience.

In contrast to his IDS, in his RDS Iosef chose metaphorical images which reflected his challenges in searching for perfection. All the images were his personal photographs, highlighting not only the TPK element but also his deep content knowledge of the woodworking component of his 
teaching subject. Louk also used personally owned images and he chose to present them in black and white because he said he wanted the RDS to have a unified aesthetic appearance and believed images with various colours would impact negatively on it. Both Maeve and Fintan illustrated TPK in their selection of images from the licensed site. Fintan chose not to use his own photographic images because of the time element it would add to the creation of the RDS. Maeve had difficulty choosing images because she spent so much time searching for the most suitable. She described how she could have continued searching but decided to conclude due to time pressure. She was still unsure about her choice of images when viewing the finished product and as a result of this, she plans to build a library of images for future IDS illustrating her intention to further develop TPK.

The creation of an RDS facilitated the development of TPACK for all teachers and enabled them to develop a deeper insight into their practice by analysing the personal use of storytelling as part of instruction and evaluating newly learned technology integration. This type of reflective practice is in line with standards of good practice proposed by the Teaching Council of Ireland [47].

In contrast to the creation of the IDS', the teachers created their stories in a short space of time. They did not have to analyse suitable topics or negotiate student audiences. They storied real experiences which they believe had an impact on their teaching intentions. They had developed a tacit knowledge during the creation of the IDS, and the planning and creation of the RDS enabled an awareness of this which provided a rich implicit knowledge thus providing stories of experience.

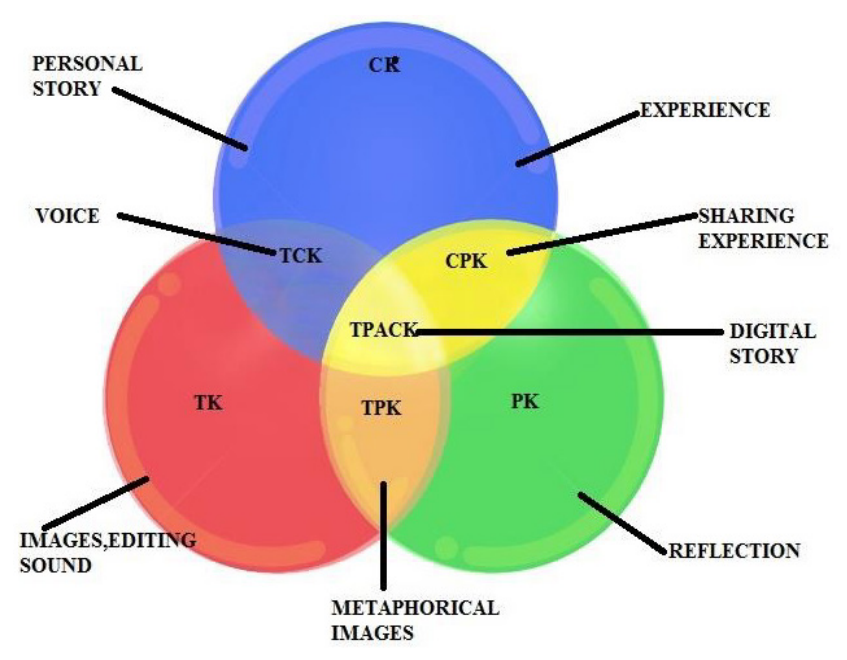

Figure 2. TPACK development based on DS

\subsection{Values and Attitudes}

All four participating teachers conveyed their beliefs and attitudes by the type of IDS they created and also indicated them in their follow-up RDS. They also voiced their beliefs and attitudes within the reflective story circle. The four teachers integrated personal beliefs into their thinking and actions when creating their IDS, something which Fintan became particularly aware of during the creation of the IDS. He expressed barriers to Digital Storytelling in the style of IDS he created and during the reflective phase when he commented 'It fitted into my lesson plan... but I didn't create a story did I?'

Iosef's awareness of his classroom management and existing relationship with junior students challenged the benefits of telling stories for instruction. His deviation from the workshop definition of IDS was linked closely to his beliefs and value of storytelling for instruction. He described managing his junior classes with a strictly student /teacher relationship which serves to distance himself as a person outside of the classroom. He sets a clear focus on teaching and learning within those boundaries. His beliefs and classroom management practice with junior students challenged the creative element of the script. Iosef remained satisfied with his use of technology for the Developments topic and the level of engagement and accelerated learning by his students, and he plans to use his personal style of IDS for future classes on the topic of Development. He did not view the creation of a story as a challenge, expressing it was a style which did not fit into his pedagogy for Junior students in his subject and supported this by saying he would consider creating an IDS with a story for senior students in the future. Digital Storytelling did not align with his current PCK.

In contrast, Maeve enjoyed her experience of storying two characters in an office situation, and this has influenced her to plan future stories involving her characters. Maeve described herself as 'not a very creative person', yet she is creatively developing her future pedagogy in a style which she believes will interest and engage her students with a deeper level of understanding and learning of a subject which has 'changed very little in the last twenty years'. Louk also applied his values and beliefs in story instruction to his IDS, bringing his personal life into the classroom, something with which he is very comfortable. Handal and Lauvas [48] theorize that every teacher has a practical theory of teaching which relates to their experience and values. Personal experience is not merely as an educator but relates back to when being educated. This is particularly true of Louk who references his past educational experiences of storytelling teachers in his school days within his RDS.

\subsection{Professional Development}

Professional development focused on learning how to create and understand how students can learn through Instructional Digital Story (IDS). Collaborative reflection provided an opportunity to quantify and share what each of the four teachers already knew, and it grounded their observations of current practice before introducing a new technological tool. By voicing their stories of experience and listening to other stories, they reassessed their classroom practice which offered an opportunity to reshape future practice McDrury and Alterio [49]. 
Together, the four teachers learned the basic process of the seven elements of crafting a good Digital Story Lambert [13]; Ohler [10], with personal emphasis. Each demonstrated their understanding by creating a personal IDS and RDS. The development of technology knowledge (TK) used to digitize stories, and pedagogical use of storying subject content (PCK) was a result of a collaborative working environment. Lave and Wenger [50] maintain that questions which arise from this type of collaborative process draw upon shared expertise and help to make a method more explicit in the context of practice. The unique style of IDS crafted by each teacher and shared in the reflective story circle developed questions among the four teachers with particular reference to the suitability of IDS for their subject, teaching style, beliefs and values. Louk had shared his RDS with Fintan and Iosef and from viewing the style of Iosef's introduction to his RDS evidence of learning from Louk can be seen. Both RDS use images of the teacher in a reflective pose.

The sociality of the process of story circle and the integration of technology involved in Digital Story alongside the nature of narrative inquiry served to nurture professional development across subject domains. This type of collaboration is unique across subjects in the secondary school where the inquiry took place and most probably unique in other secondary schools in Ireland. This relates to hierarchical issues of subjects within a school curriculum.

\subsection{Hierarchy of Subjects}

Optional subjects such as Business and Design Communications Technology often compete for student numbers and therefore teachers work very closely as a department, to the point of almost becoming insular. Core subjects of Mathematics and English are highly valued because success is crucial to achieving either the junior or Leaving Certificate State examination and may be viewed by some teachers and school management as having higher status on the curriculum. Throughout the process of the inquiry, the four teachers treated all four subjects as having equal value on the curriculum as they shared a common goal of developing TPACK.

\subsection{Relationships}

Over the professional development process, a sense of connectedness and caring among the group was indicated through sharing of TK outside of the meetings. These factors are highlighted as important in narrative inquiry by Connolly and Clandinin [51] when they say: 'In everyday life the idea of friendship implies a sharing, an interpenetration of two or more persons' spheres of experience. Mere contact is acquaintanceship not friendship. The same can be said for collaborative research which requires a close relationship akin to friendship'. (p. 281)

The three male teachers developed a relationship parallel to friendship. They collaborated and shared information outside of the story circle, but did not include the female teacher. Maeve treated this casually when she described how she did not make an effort to collaborate with them. Iosef and Maeve teach in classrooms which are located on the same floor of the school and would, therefore, meet regularly. The male teachers informed me how they collaborated during the school day. This inquiry did not lend itself to explore why this happened, but it does highlight the possibility of gender or other issues.

As the inquiry progressed, I listened to and observed the participants and became aware of living their shared stories of Digital Story challenges and difficulties and the fact that both researcher and participant should be heard. I displayed my trust in the group relationship by sharing an RDS I had created based on the inquiry to date. The process of sharing my RDS created further discussion and opened greater avenues of trust within the group. It encouraged the teachers to voice their fears and challenges at a deeper level illustrating the nature of collaboration as part of professional development. All four teachers reported having found collaboration as a group within the school to be a positive experience. They discussed how they chose to collaborate and this influenced their commitment to integrating the technology of Digital Story into their pedagogy. Sharing of experiences inspired Iosef to suggest he would create an IDS with a story plot for senior students, Maeve has been inspired to develop a series of IDS and while Fintan and Louk do not plan to continue unless they are allocated time to do so, they found it a rewarding and enjoyable experience.

\section{Conclusions}

This Paper has illustrated how links between a community of practice and student learning can be generated in a school setting. It has gained insight into rewards, challenges and concerns of teachers who shared experience of developing TPACK after the creation of Digital Stories through the roles they play in the school curriculum. Rewards included successful experiences of accelerated student learning and feelings of pride in their personal mastery of creating both IDS and RDS. While challenges of time consumed in the creation and personal choice of utilizing DS were balanced through participation in a professional learning community.

The experience of networking became enriched by the curiosity of other teachers within the school. Innovative practice such as IDS inspired other teachers within the school community to ask questions and created further openness to observation and learning. The evolving process of understanding is gained from learning networks and Digital Storytelling encourages collaborative networks through the story circle process. It is during this process that ideas, techniques and challenges which have been overcome are shared. It encourages teachers to discuss and share nontraditional methods of teaching and consider methods 'providing a clear explanation of subject matter, using a 
variety of approaches' (p. 13) ESRI [52].

The experience of the four teachers participating in this inquiry highlighted the integration of technology as a complex issue. As they engaged in a new experience they displayed differing levels of confidence, belief and creative thinking. Based on the ontological beliefs of two teachers, Digital Storytelling as an instructional tool can develop a teachers understanding of TPACK. The interaction of the six elements TK, PK, CK, TPK, TCK, PCK can assist the teacher selecting knowledge in a more strategic and varied way. It can focus the instructional planning in making instructional decisions which has the potential to engage and accelerate student learning. One teacher demonstrated how beliefs do not always match practice when he became influenced by curriculum requirements. This indicates how teachers utilize a particular technology in different ways and TPACK alone does not provide an explanation as to why.

Reflection is a necessary component when learning a new digital media and this assisted in developing an understanding why the participating teachers utilized IDS in different ways. As a reflective tool Digital Storytelling enhances the process of reflection and offers an opportunity for teachers to question their practice. It also maintains a structure for the process of creative thinking and exposes teacher attitudes and sense of self efficacy. The use of personal narrative in creating an RDS encourages teachers to articulate implicit knowledge and reflect on personal experience of bringing together knowledge of technology, content and pedagogy. This suggests a need for further research with experienced teachers

This practitioner based research shows how teachers across the curriculum have the potential to collaborate and share resources, knowledge and creative solutions while developing TPACK. In doing so, they can establish a community of practice (CoP) with a particular focus, such as IDS, within a larger community of teachers. The contribution of this research to learning environments within a domestic school setting has illustrated how educational thinking and practice across subject disciplines can be altered.

\section{REFERENCES}

[1] MISHRA, P. and KOEHLER, M. (2006) Technological Pedagogical Content Knowledge: A framework for teacher knowledge. Teachers College Record, 108 (6), pp. 1017-1054.

[2] THE TEACHING COUNCIL (2014) Draft framework for teachers learning Cosán [Homepage of The Teaching Council.ie], [Online].

Available:

www.teachingcouncil.ie/en/Teachers-Education/Doc [7/7/2015, 2015].

[3] MISHRA, P. (2015) Personal Communication. Mite Conference: Galway, Ireland.

[4] OECD. (2009) Teaching and Learning International Survey:
Creating Effective Teaching and Learning Environments. First Results from Talis [Homepage of OECD], [Online]. Available:www.oecd.org/edu/school/43023606.pdf $\quad[2 / 5$, 2015].

[5] THE TEACHING COUNCIL (2011) Policy on the Continuum of Teacher Education [Homepage of Teaching Council], [Online]. Available:

www.teachingcouncil.ie/en/Publications/Teacher-Education/ Policy-on-the-continuum-of-Teacher-Education.pdf [20/7/2015, 2015].

[6] CENTRE for DIGITAL STORYTELLING. https://www.storycenter.org/

[7] SHULMAN, L.S. (1987) Knowledge and teaching foundations of a new reform. Harvard Educational Review, 57(1), pp. 1-21.

[8] MISHRA, P. and KOEHLER, M. (2006) Technological Pedagogical Content Knowledge: A framework for teacher knowledge. Teachers College Record, 108 (6), pp. 1017-1054.

[9] MCGEE, P. (2015) The Instructional Value of Digital Storytelling. New York: Routledge.

[10] OHLER, J. (2008) Digital Storytelling in the Classroom: New Media Pathways to Literacy, Learning and Creativity. (1st edn) Thousand Oaks, CA: Corwin Press.

[11] ROBIN, B. (2008) Digital Storytelling: A powerful technology tool for the 21 st century classroom. Theory into Practice, 27, pp. 220-228.

[12] THOMPSON LONG, B., (2014) Designing Digital Storytelling: Creative Technology for Reflection in Initial Teacher Education. Ph.D edn. Galway: NUI Galway.

[13] LAMBERT, J. (2013) Digital Storytelling: capturing the lives of the community. (4th edn) New York, London: Routledge.

[14] MEADOWS, D. (2008) A Guide to Digital Storytelling [Homepage of BBC Capture Wales Team], [Online].Available: www.bbc.co.uk/.../aguidetodigitalstoryt.. [June, 2015].

[15] OECD. and UNESCO. (2001) Teacher's for Tomorrows Schools: Analysis of the World Education Indicators. Paris: OCDE/Unesco.

[16] LLORENS, S., SLLANOVA, M. and CHARLESWORTH, R. (2002) Training to Technological Change. Journal of Research on Technology Education, 35 (2), pp. 206-212.

[17] .LAWLESS, K.A. and PELLEGRINO, J.W. (2007) Professional Development in Integrating Technology into Teaching and Learning: Knowns, unknowns and ways to pursue better questions and answers. Review of Educational research, 77(4), pp. 575-614.

[18] ALDERMAN, N., DONNELLY, M.B., TIFFANEY-MORALES, J., WAYNE, A. and ZUCKER, A. (2002) The integrated studies of educational technology: Professional development and teachers' use of technology. Arlington, VA: SRI International.

[19] DESIMONE, L.M., PORTER, A.C., GARET, M.S., YOON, K.S. and BURMAN, B., (2000) Effects of Professional development on Teachers Instruction: Results from a Three Year Longitudinal Study. Education Evaluation and Policy Analysis, 24(2), pp.81-112.

[20] SPARKS, D. (2002) Designing Powerful Professional 
Development for Teachers and Principals [Homepage of National Staff Development Council], [Online]. Available: www.friscoisd.org [September, 2015].

[21] CLARKE, L. (2015) Teacher education: affordances and barriers, Jan 23rd 2015, Mite Conference.

[22] CLANDININ, D.J. (2007) Handbook of Narrative Inquiry. Thousand Oaks, CA: Sage Publications.

[23] CLANDININ, D.J. and CONNELLY,F.M. (2000) Narrative inquiry: Experience and story in qualitative research. San Fransisco, CA: Jossey-Bass.

[24] CORTAZZI, M. (2001) Narrative analysis in ethnography. In: P. ATKINSON, ed, Handbook of Ethnography) (eds) London: Thousand Oaks, pp. 384-394.

[25] CONNELLY, F.M. and CLANDININ, D.J. (1999) Shaping a professional identity: Stories of educational practice. New York: Teachers College Press.

[26] DOECKE, B., BROWN, J. and LOUGHRAN, J. (2000) Teacher talk: The role of story and anecdote in constructing professional knowledge for beginning teachers. Teaching and Teacher Education, 16(3), pp. 335-348.

[27] GOODSON, I.F. (1995) The story so far: Personal Knowledge and the Political. In: J.A. HATCH and R. WISNIEWSKI, eds, Life History and Narrative (Eds). London: Falmer Press, pp. 89-98.

[28] JALONGA, M.R. and ISENBERG, J.P. (1995) Teachers' Stories: From Personal Narrative to Professional Insight. San Fransisco: Jossey-Bass.

[29] RAYMOND, D., BUTT, R. and TOWNSEND, D. (1992) Contexts for Teacher Development: Insights from Teachers Stories. In: A. HARGREAVES and N.G. FULLAN, eds, Understanding Teacher Development. London: Cassell, pp. $143-161$

[30] ELBAZ-LUWISCH, F. (2002) Writing as inquiry: Storying the teaching self in writing workshops. Curriculum Inquiry, 32(4), pp. 403-428.

[31] ETHERINGTON, K. (2004) Becoming a Reflexive Researcher: Using Our Selves in Research. London: Jessica Kingsley Publishers.

[32] GERGEN, K.J. and GERGEN, M.M. (1986) Narrative form and the construction of psychological science. In: T. SARBIN, (ed) Narrative Psychology: The Storied Nature of Human Conduct. New York: Praeger, pp. 22-44.

[33] SARBIN, T.R. (1986) The narrative as root metaphor for psychology. In: T.R. SARBIN, ed, Narrative Psychology: The storied of human conduct. New York: Praeger, pp. 3-21.

[34] CONNELLY, F.M. and CLANDININ, D.J. (2006) Narrative Inquiry. In: J. GREEN, G. CAMILLI and P. ELMORE, (eds) Handbook of complimentary methods in education research. Mahweh, NJ: Lawrence Erlbaum, pp. 477-487.

[35] SMITH, B. and SPARKES, A. (2009) "Narrative inquiry in sport and exercise psychology: What can it mean, and why might we do it?" Psychology of Sport and Exercise, 10 (1), pp. $1-11$.

[36] CLANDININ, D.J. (2007) Handbook of Narrative Inquiry. Thousand Oaks, CA: Sage Publications.
[37] JOHNSON, G. (2002) Using Visual narrative and post structuralism to re(read) a student teachers professional practice. Teaching and Teacher education, 18(4), pp. 387-404.

[38] GOMEZ, A. and GOMEZ, R. (2002) Personality traits of the behavioural approach and inhibition systems. Associations with processing emotional stimuli. Personality and Individual Differences, 32(8), pp. 1299-1316.

[39] LAMBERT, J. (2013) Digital Storytelling: capturing the lives of the community. (4th edn) New York, London: Routledge.

[40] DENZIN, N.K. and LINCOLN, Y.S. (1994) Handbook of Qualitative Research. Thousand Oaks: Sage.

[41] ANDREWS, H. (2010) Story Types and the Hero Story. In: D.H. ANDREWS, T.D. HULL and K. DEMEESTER, (eds) Storytelling as an Instructional Method. Rotterdam, Boston: Sense Publishers, pp. 3-9.

[42] PORTER, B. (2004) Digi Tales: The Art of Telling Digital Stories. USA: Digi Tales Story Keepers.

[43] CHARMAZ, K. (2014) Constructing Grounded Theory. (2nd ed) Los Angeles, London, New Delhi, Singapore, Washington DC: Sage Publications.

[44] SHANK, R., BERMAN, T. and MACPERSON, K.A. (1999) Learning by doing. In: C.M. REIGELUTH, (ed) Instructional design theories and models: A new paradigm of instructional theory (Vol. II). NJ: Mahwah, Lawrence Associates, pp. 161-181.

[45] ERTMER, P.A., GOPALAKRISHNAN, S. and ROSS, M. (2001) Technology- Using Teachers. Comparing Perceptions of Exemplary Technology Use to Best Practice. Journal of Research on Computing in Education, 33(5).

[46] RODGERS, C. (2002) Defining Reflection: Another look at John Dewey and reflective thinking [Homepage of Teachers College Record, 104 (4) [Online]. Available: http://www.jcu.edu/education/ed100/Rodgers,[August, 2015].

[47] THE TEACHING COUNCIL (2011) Policy on the Continuum of Teacher Education [Homepage of Teaching Council], [Online].Available:

www.teachingcouncil.ie/en/Publications/Teacher-Education/ Policy-on-the-continuum-of-Teacher-Education.pdf [20/7/2015, 2015].

[48] HANDEL, G. \& LAUVA, P. (1987). Promoting reflective teaching: supervision in practice (Milton Keynes, Open University Enterprises).

[49] MCDRURY,J., ALTERIO,M., 2002. Learning through Storytelling in Higher Education. London: Kogan Page.

[50] LAVE, J. and WENGER, E. (1991) Situated learning: legitimate peripheral participation. Cambridge England; New York: Cambridge University Press.

[51] CONNELLY, F.M. and CLANDININ, D.J. (1988) Teachers as curriculum planners: Narratives of experience. New York: Teachers College Press.

[52] ESRI. (2007) Research into the experiences of students in their third year of junior cycle and in transition to senior cycle [Homepage of NCCA], [Online]. Available: www.ncca.ie/uploadedfiles/publications/ESRI_3rdYr.pdf [July, 2014]. 